NG, Kwai Hang, and Xin HE. 2017. Embedded Courts:

Judicial Decision-Making in China. New York:

Cambridge University Press

Book reviews

\title{
Peifan Li
}

\section{(2) OpenEdition}

\section{Journals}

Electronic version

URL: http://journals.openedition.org/chinaperspectives/8571

DOI: 10.4000/chinaperspectives.8571

ISSN: 1996-4617

\section{Publisher}

Centre d'étude français sur la Chine contemporaine

Printed version

Date of publication: 31 December 2018

ISSN: 2070-3449

\section{Electronic reference}

Peifan Li, « NG, Kwai Hang, and Xin HE. 2017. Embedded Courts: Judicial Decision-Making in China. New York: Cambridge University Press », China Perspectives [Online], 2018-4 | 2018, Online since 12

February 2019, connection on 23 September 2020. URL : http://journals.openedition.org/ chinaperspectives/8571 ; DOI : https://doi.org/10.4000/chinaperspectives.8571

This text was automatically generated on 23 September 2020.

(C) All rights reserved 


\section{NG, Kwai Hang, and Xin HE. 2017. Embedded Courts: Judicial Decision- Making in China. New York: Cambridge University Press}

Book reviews

\section{Peifan Li}

1 Since Reform and Opening in the 1980s, the judiciary in China has experienced significant development alongside the country's rapid economic growth and global market integration. State-led professionalisation has led to the belief that Chinese courts are becoming increasingly similar to their Western counterparts. However, this belief is based on the assumption that the legal system is a homogeneous judicial entity conforming to powerful top-down policies, an assumption contradicted by the

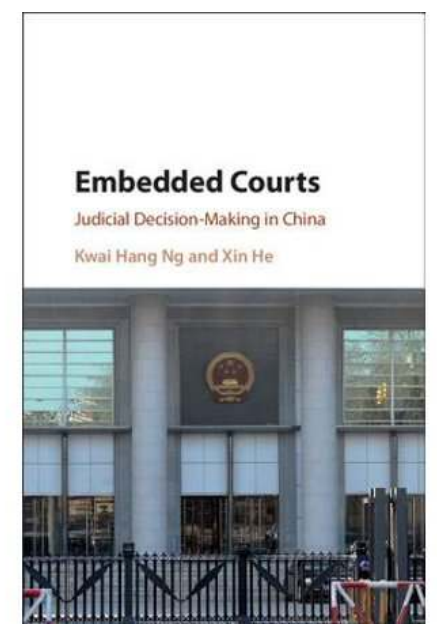
narratives of regional disparity recounted in Embedded Courts: Judicial Decision-Making in China. In this book, Ng and He suggest that the operational patterns of Chinese courts are not monolithic. Beneath the courts' surface uniformity in implementing laws lies significant heterogeneity. In their study of the underlying mechanism causing this heterogeneity, $\mathrm{Ng}$ and He have identified four types of forces: administrative, political, social, and economic embeddedness, and they vividly depict how Chinese courts adapt to these external influences.

2 The book begins by contrasting the working scene of a court in a developing area versus that in a developed one, identifying two typical operational patterns: "work-unit 
courts" and "firm courts" (pp. 6-7). These two types of courts are quite different in terms of four key attributes: "vertical hierarchy, administrative nature of decisionmaking process, the organization-oriented model of promotion and the role of the court for its judges" (p. 8). The term "work-unit" refers to the socialist and collectivist employment system, while the "firm courts" are organised according to a "quasimarket mechanism" (p. 12). In a work-unit court, tight vertical control is more important than efficiency; social skills are deemed more important than expertise and knowledge, and judges rely heavily on socio-economic welfare provided by the courts. Firm-type courts, on the other hand, have a "weakened hierarchy" (p. 12), a "tendency to use more law" (p. 13), an enhanced role of professionalism, and fluid employment of judges.

3 Chapter 2 describes the different components of frontline judges' daily work and the "structurally porous" (p. 53) judicial process in Chinese courts. They depict the three main sections of the judges' work routine: adjudications, mediations, and postjudgement work, and reveal the features of judges' investigations, the administrative hierarchy of courts, and the increasingly individualistic operations of collegial panels. Chapter 3 focuses on generational differences between cohorts of judges divided into three groups: veteran, middle-aged, and post-1980s. These cohorts differ substantially in their training background, administrative identity, and professional or technocrat mentality. As suggested by the authors, the Chinese judiciary has experienced a process of "intellectualization" (p. 74). Post-1980s judges are more reluctant than their predecessors to submit to administrative control; they admire professionalism and value the use of laws. This generational tension regarding outcome-oriented management also reflects attempts by the Supreme People's Court (SPC) to manage regional fragmentation by promoting legal coherence through education. In this chapter, $\mathrm{Ng}$ and $\mathrm{He}$ also envisage that the firm-type mentality will become increasingly dominant in China based on the supersedence of the judiciary.

Chapter 4 studies administrative embeddedness and explores how the various components of judges' work rounds are related to each other. $\mathrm{Ng}$ and He use the minutes of a work-unit court's adjudication committee to investigate the bureaucratic nature of Chinese courts. The administrative hierarchy of the committee is organised according to the principles of professional competence and collegiality to a limited extent, but administrative rank overrides legal expertise; senior judges use both formal and informal methods to influence the judgements of junior judges. In the firm court, this vertical control is less common, partly because of the heavy caseload, so the hierarchy appears to be flatter. However, internal administrative supervision is only one facet of administrative embeddedness, as the blurred boundary between the judiciary and other party-state institutions facilitates external administrative impact on the courts. For example, it is common for senior judges with administrative power to have experience working in other party-state organs. In addition, court presidents are usually members of the Political-Legal Committee (PLC), which is a major component of the local party-state. They are hence responsible for serving as a linkage to facilitate the "local party coalition" (p. 109) in some political or state actions, such as resolving collective social protests or legitimising some administrative processes. The dual roles of the senior judges create a "hand-in-glove relationship" (p. 120), in which external administrative impact is reinforced through internal administrative authority. 
Chapter 5 examines political embeddedness, or the "instrumental nature of law in promoting broader government operations of stability maintenance" (p. 122). Compared to their Western counterparts, Chinese courts have long been subject to political concerns rather than to promotion of law. Nowadays, political concerns prioritise stable governance, influencing the judicial system in four ways. First, the judiciary is accountable to the People's Congress at the same level; second, the courts are involved in many stability-maintenance actions, some of which are even outside the realm of law; politics sometimes hinder the issuing or exercising of legal determinations; the penetrating political impacts also set limits on the exercise of law. $\mathrm{Ng}$ and $\mathrm{He}$ discuss political embeddedness using specific cases involving petitions, highly contested divorce, and housing demolition. Judges are reluctant to adjudicate cases that might trigger petitions, for fear of the petitioning system, which blames legal practitioners rather than the law per se. In contested divorce cases, judges assess the mental condition of both parties and the potential risk of conflict escalation and then propose a solution that can minimise malicious incidents. In housing demolition cases, litigation has become an instrument to uphold collective social protests. Compared with that of firm courts, the extent to which judges are eager to maintain social and political stability is greater in the work-unit courts in developing areas, and in recent years, the tension between promoting stability and implementing laws has become increasingly prominent as China has urbanised.

6 Chapter 6 mainly deals with social embeddedness, which refers to the influence of social ties on the judicial decision-making process. Social ties affect judges' decisionmaking through both cultural and institutional paths: horizontal influence from members of their private circle, to whom judges feel a sense of obligation, and vertical influence from administrative superiors, who can influence judges' career advancement or welfare distribution. $\mathrm{Ng}$ and He suggest that superior and strong ties bring the most significant impact, whereas non-superior and weak ties are the least influential, and non-superior but strong ties and superior but weak ties have strong but limited influence. In work-unit courts, the vertical administrative relationship is stronger than in firm courts because judges rely heavily on welfare allocated by their supervisors; therefore, social embeddedness manifests itself more than in firm courts. Hence, the authors also point out the interplay of social embeddedness and other forces.

7 The last part of this book examines the economic embeddedness that determines the degree of a court's fiscal independence from local government. Since the 1990s, in order to deliver affordable judicial services, Chinese courts have adopted a "dual-track" policy that unhooks funding of the courts from the revenue they make. However, some courts, especially work-unit courts in less-developed areas that are short of funds, have to justify their deficit to local governments in order to obtain further fiscal support. For firm courts, the abundant income derived from litigation fees and other sources has enabled them to operate without the need for budgetary funds; this secures their political autonomy to some extent. It also reduces administrative control of frontline judges by senior judges.

8 This book synthesises the authors' comprehensive research and penetrating insights into the Chinese court system and provides abundant empirical evidence to understand the mechanism of the Chinese judicial system's heterogeneity. The analysis sheds light on how Chinese judges adapt to constraints and exert their authority. When presenting 
the four types of embeddedness, $\mathrm{Ng}$ and He by no means treat them in a disparate way, but implicitly embrace the interplay of different forces. For instance, it is suggested that heavy administrative control can reinforce the effects of social embeddedness, while the growth of self-supporting fiscal income can limit vertical administrative control. However, the authors place great emphasis on how economic embeddedness influences the extent to which the courts are embedded in the other three aspects but not vice versa. The overemphasis on economic embeddedness confines the analysis within a limited local scope and overlooks the nature of competition (Zhou 2004) among local governments under the party-state system, and thus puts the courts into a passive position where they need to adapt to these types of forces. The book's second author, in fact, has proposed elsewhere the idea of "spill-over effect," revealing that successful local innovation in one place may trigger a change of state law or regulation and influence the judicial practice in other places (He 2013). Moreover, when discussing administrative embeddedness, the authors examine evidence mainly drawn from a work-unit court, and the lack of depiction in developed areas may limit the readers' understanding of firm courts. Nevertheless, this impressive work, based on solid qualitative research, provides vivid depictions of the tensions, constraints, and struggle confronting the courts in China's seemingly uniform judicial system, thereby facilitating an understanding of the path of judiciary professionalisation in China.

\section{BIBLIOGRAPHY}

HE, Xin. 2013. "Judicial Innovation and Local Politics: Judicialization of Administrative Governance in East China." China Journal, 69: 20-4.

ZHOU, Li-An. 2004. "The Incentive and Cooperation of Government Officials in the Political Tournaments: An Interpretation of the Prolonged Local Protectionism and Duplicative Investments in China." Economic Research Journal, 6: 33-40.

\section{AUTHOR}

\section{PEIFAN LI}

Li Peifan is a PhD candidate in the Department of Sociology, The University of Hong Kong.lipeifan@hku.hk 